\title{
Innovative Financing of the Sustainable Development Goals in the Countries of Western Balkans
}

Igor Luksic ( $\nabla$ igor.luksic@icloud.com )

Univerzitet Donja Gorica https://orcid.org/0000-0002-7187-5547

Bojana Boskovic

Univerzitet Donja Gorica

Aleksandra Novikova

Institute for Climate Protection

Rastislav Vrbensky

Masaryk University

\section{Original article}

Keywords: Sustainable/ESG bonds, debt swaps, Western Balkans public debt, sustainable development goals, EU accession

Posted Date: September 15th, 2021

DOI: https://doi.org/10.21203/rs.3.rs-853207/v1

License: (c) (i) This work is licensed under a Creative Commons Attribution 4.0 International License. Read Full License 


\section{Abstract}

Background: This paper is related to the current stage of the development in the Western Balkans. Despite becoming a growing instrument to finance sustainable development green, debt swaps and social or sustainability bonds are a relative novelty in this region. At the same time the development needs are huge, especially in the light of the Covid-19 aftermath.

Results: We have analyzed the public debt position in the Western Balkans countries which points to the deteriorated new debt accumulation perspective especially in the light of the growing public debt over the past decade. Our research suggests that the ESG/Sustainability-linked bonds and debt-for-climate swaps as innovative financial instruments seem to be promising to leverage additional finance into sustainability goals in the Western Balkans Six given their need on the EU track and their economic and structural challenges. After briefly discussing the methodological approach, we discuss the history and features of green bonds and debt-for-nature swaps and their diverse underlying mechanisms. Then we derive recommendations for policymakers in designing future green bonds and debt-for-nature swaps and apply these to national circumstances in the Western Balkans Six.

Conclusions: The related countries need to explore more innovative approaches to finance sustainable societies. In the close cooperation with the EU and related to the European Green Deal countries of the Western Balkans six should feel motivated to design financing mechanisms that will bring in the more transparency into the different policies and the more accountability for their implementation. The EU should stand ready to use its cohesive and pre-accession funds to support such market mechanisms, which can bring the cooperation to the next level. Applying the recommended modality may help keep the problem of the public debt be kept at bay while additional funds may support implementation of thestructural reforms.

\section{Introduction}

The adoption of the seventeen Sustainable Development Goals (SDGs) in 2015 by the UN General Assembly marked the beginning of the new era for the global policy coordination. Following the Millennium Development Goals adopted in 2000, the SDG or UN 2030 Agenda becomes the anchor agenda for all the stakeholders. The United Nations (UN), individual countries, corporations, multilateral financial institutions and so on all the way to those who are most affected by both the success or failure of it - the ordinary people all over the globe.

The implementation of the UN 2030 Agenda is evidently costly and according to the UN study it is between USD 3.3-4.5 trillion per year that needs to be mobilized to fund different projects, development programs and various initiatives which help countries achieve these ambitious goals (UNSDG, 2018). According to the same study, developing countries face an average annual funding gap of USD 2.5 trillion. It is clear that government-driven or multilateral aid institutions-led support needs to be complemented by the private sector and the abundant funds that are available on the markets. The task for policymakers and the private sector investors is, therefore, to coordinate and look for the more innovative approaches. As far as the European area is concerned the game changer is the adoption of the European Green Deal which set the stage by introducing clear goals and investment needs to turn around the economy by 2050 (European Commission, 2019).

Innovative instruments are needed to scale up international finance for sustainability purposes, but only limited options are available for developing and transition economies (SCF UNFCCC, 2018). For instance, the largest share of adaptation finance was provided through grants (77\%), while concessional loans (17\%), and blended grant/loan and other instruments (6\%) only played a subordinate role (Pandit et al., 2017). Mitigation finance was provided mostly through loans and blended finance instruments (ibid). On one hand, many bi- and multilateral donors report a challenge of disbursing their funds as they fail to identify fundable projects. On the other hand, many developing countries report difficulties in accessing available resources due to lack of capacities and the inability to fulfil specific requirements established by donors or financing institutions (ibid). High external debt burdens further hamper many developing countries in accessing finance and setting their economies on a sustainable path.

In the meantime, the countries of the Western Balkans Six (Albania, Bosnia and Herzegovina, Kosovo, Montenegro, North Macedonia, and Serbia) struggle to juggle all the policymaking tools to achieve sustainable economic development. In parallel, they are supposed to meet benchmarks in the number of complex fields while achieving good grades related mostly to the rule of law, quality public administration and economic governance in order to join the EU.

One of the aspects that will be under particular scrutiny is the debt portfolio of the countries in question and the possibilities to improve the current situation given the sustainable development requirements. This is of particular importance as it is important to address potential that lies ahead in using the innovative means of financing the development policy needs.

Despite the fact that the early green bonds attempts are more than a decade long (Peeters et al., 2020), this new mechanism of issuing green, social or sustainability bonds (including the sustainability linked variation) has been gaining growing traction in the recent years globally. However, it still represents a novelty in the region of the Western Balkans where countries have mostly been oriented to the classic bond market for the budget needs and international financial intermediary's (IFI) project financing for other purposes. The reliance on the IFI's, at least the ones which are based in Europe and including the World Bank group has brought the need to implements certain standards which has made countries comply indirectly with some of the principles of the sustainable development.

Debt-for-nature swaps (and swaps for other sustainability purposes) offer another solution to avert both debt and sustainability challenges by providing debt relief alongside mobilizing new finance for achieving sustainability goals. While respective designs vary, all debt swaps share the same underlying mechanism: public debt of a developing country is cancelled in exchange for investments in projects linked to nature protection within the debtor country. There have only been a few debt-for-nature swaps in countries of other world regions so far, and we recorded one debt swap in Montenegro - while we could, however, identify a recent surge in scholarly attention. 
It is time the next step was made. Do these new financing mechanisms offer the opportunity to bring more transparency into the policy making and more accountability for its success? Can those mechanisms be more financially opportune and thus create additional space for the development needs? Would EU further support countries along the accession road?

The aim of this paper is to assess new sustainability-linked bonds and debt-for-climate swaps as innovative financial instruments promising to leverage additional finance into sustainability goals in the Western Balkans Six. After briefly discussing the methodological approach, a literature review shines light on the history and features of green bonds and debt-for-nature swaps and their diverse underlying mechanisms. The subsequent section derives recommendations for policymakers in designing future green bonds and debt-for-nature swaps and applies these to national circumstances in the Western Balkans Six. This study ends with conclusions highlighting key messages.

\section{Methodology}

For this study, two main methods were employed. As a first step, online search was conducted for published material on sustainability bonds and debt swaps by researchers, international institutions and think tanks. This also entailed the collection of reports, news articles, and web pages. All collected data was then reviewed and analyzed from the perspective of drawing useful recommendations for the focus countries. Second, we analyzed relevant data related to the debt situation in the countries and draw conclusions on the usability of instruments based on our experience in policymaking in the region.

\section{Literature review}

\section{Green, Social and Sustainability Bonds History of green, social, and sustainability bonds}

All the new forms of the bonds are voluntary. However, the growing trend is obvious. Investors tend to identify benefits either due to their interest to approach markets in different ways, either because it raises the countries or corporations visibility or because it opens new financing channels as more and more investments funds commit to keep share of their investments in the green, social or sustainability bonds (Climate Bonds Initiative, n.d.) or as they are more and more referred as ESG instruments.

One of the consequences of the COVID-19 related to this new bond market was the slow-down of the green bonds against the growth of the social and sustainability bonds. The social bonds hit record with the increase of $170 \%$ since the beginning of 2020 . However, despite rising corporate interest, the rapid increase in social bond issuances as a response to the recent pandemic has been mainly led by IFls and primarily multilateral development banks (MDBs) (Peeters et al., 2020). In parallel to that there is an expectation that there will be a need to restructure sovereign debt in a number of countries for which a more innovative approach may be needed (Willems, 2021).

The Green Bonds Principles just like the Social Bonds Principles or the Sustainability Bonds Principles are designed to promote the transparency and integrity needed to increase capital allocation to the projects that highlight either the green or social element (or the mix). It makes them related to the sustainability policy as explained by the International Capital Markets Association's briefs (ICMA, 2019; International Capital Market Association (ICMA), 2020). In order to muster more resources needed for the SDG financing the best avenue to take is to increase transparency about what are the financing goals and what are the policy makers directions in the mid to the long run.

Having been launched in 2007, with the European Investment Bank and the World Bank, issuance of the green market bond has significantly grown. The wider bond market started to react after the first USD 1 billion green bond sold within an hour of issue by IFC in March 2013, while in November the same year corporate green bonds started to see the light. The key year was 2014 when USD 37 billion worth bonds were issued, while the new record was set in 2019 when issuance reached almost USD 259 billion. The cumulative issuance since 2007 stands at USD 754 billion across 5,931 deals and 927 issuers, while so called certified climate bonds reached USD 100 billion milestone (Climate Bonds Initiative, 2020).

Normally the projects funded are related to the climate change mitigation, climate change adaptation, natural resource conservation, biodiversity conservation, and pollution prevention and control, being focused for example on energy or emissions reduction projects, sustainable agriculture, and green buildings.

On the other hand, the social bonds are intended to meet various social needs. Their role is to provide capital for projects that contribute to socioeconomic advancement and empowerment such as affordable housing and infrastructure, access to essential services, employment generation, and food security (The Economist, 2021). They are similar in structure to green bonds, a particularly popular form of "use of proceeds" bonds (Peeters et al., 2020). Logically, the target populations include poor people living under the poverty line, undereducated ones, marginalized groups and so on.

All these new instruments require vigilante reporting by external parties who monitor and certify accomplishments which adds to their credibility and makes them potentially preferred mechanism in the mid to the long term for the needs to meet SDG benchmarks and help decarbonize economy whilst making best use of the private public partnerships. However, the magnitude of the needs is very large. Communicating the European Green Deal in December 2019 , the Commission estimated the need of additional EUR 260 billion per year or about 1.5\% of 2018 GDP in order to reach energy and climate 2030 goals (European Commission, 2019). It is obvious that the new financing mechanism need to be given boost.

The current total value of outstanding green, social and sustainability bonds is USD 1,503 billion (Environmental Finance Bond Dabatase, n.d.). However, as IFC team in their note point out green, social, and sustainability bonds still only make up a fraction of the overall of the bond market. Compared to green bonds, the social bond market is still in its nascent stage. However, issuances have skyrocketed since the outbreak of COVID-19 in early 2020 , as social bonds have become of increasing interest to investors looking to achieve positive social outcomes together with a financial return (Peeters et al., 2020). 
There is still a lot to do when it comes to the regulatory framework especially now that the sustainable finance becomes rather part of the mainstream. The green transition in various sectors can be significantly supported by some of these sustainability or performance linked mechanisms. Therefore, it is expected that the EU will further work in this field by creating EU Green Bond Standard (EU Technical expert group on sustainable finance, 2019) including defining EU Taxonomy (Taxonomy : Final Report of the Technical Expert What Is the EU Taxonomy ?, 2020) with the reference to the guidelines and disclosures. In the meantime, Climate Bonds Initiative has launched Climate Bonds Standard 3.0 aiming to improve the overall business environment (Climate Bonds Initiative, 2020).

\section{Examples of sustainability bonds worldwide}

Demand for green bonds is continuously increasing. Until roughly 2012, the green bond market was dominated by multilateral development banks, who already had in place processes for assessing environmental, social and governance (ESG) risks for projects. This has however changed over time, with a growing number of green bond issuances by corporates, energy and utility companies and governments and their agencies from around the world. Notable examples include Chinese issuers, who in 2016 made up about $40 \%$ of the overall green bond market, as well as Poland, which in the same year became the first sovereign to issue a green bond, followed by France, which issued the largest ever and longest-dated benchmark green bond, a Euro 7 billion, 22 -year benchmark bond. In 2017, while becoming the COP23 Presidency, Fiji became the first sovereign emerging market issuer of green bonds with a USD 50 million green bond (World Bank, 2017).

By now, more than $90 \%$ of all new green bonds had come from issuers other than multilateral development banks. This is illustrated, for instance, by the ranking of the largest climate bond issuers in 2019. Fannie Mae, the pioneer of issuing Green Mortgage-backed Securities (MBS), remained the largest green bond issuer with USD $22.9 \mathrm{bn}$ issuance or $9 \%$ of the total. KfW, the German state-owned development bank, was the second largest issuer with a total of USD $9 \mathrm{bn}$ worth of green bonds in the market with proceeds used to provide financing or co-financing to renewable energy and green building projects. They were followed by the Dutch State Treasury Agency (DSTA) ranked as the third largest issuer with USD6.7bn debut green sovereign bond.

Another recent example is the announcement of global biopharmaceutical company Pfizer to launch a \$1 billion sustainability bond offering, with the use of proceeds including funding R\&D and capex for the company's COVID-19 vaccine. The 10-year bond was priced at 1.75\%. The issue marks the second for Pfizer under its Sustainability Bond Framework, following a \$1.25 billion 2.625\% 10-year offering in March of last year. According to the company, proceeds from the offering will be used to finance or refinance research and development expenses related to COVID-19 vaccine research and development, capital expenditures in connection with the manufacture and distribution of COVID-19 vaccines, and other projects of Pfizer or any of its subsidiaries that have environmental and/or social benefits (esgtoday.com, Kerencheva, 2021).

\section{Incentives for green bonds issuance}

Although to date there has been very little academic work in the theory of the growth of the green bond market in the academic literature (Maltais, Nykvist, 2020), some conclusion can already be made. In general, the financial incentives for investing in green bonds are no different than for other asset classes. An investor has financial incentive to invest in a green bond if this bond provides some or all the following benefits: better returns, lower risk, and better diversification benefits than other comparable assets. An issuer has a direct financial incentive to issue a green bond if the green bond reduces their cost of capital and/or improves their access to capital.

Besides incentives related to the economic performance of the investor there are incentives that are not directly related to the financial performance of the green bond. Hockerts (2015) highlighted four types of non-financial business case incentives: operational, efficiency branding, creating new markets, and reducing risk. Operational efficiency could be enhanced by attracting high quality employees, making impact on the productivity of employees motivated by sustainability commitments (Branco and Rodrigues, 2006). The branding benefits of engaging in sustainable finance include attracting and retaining customers or changing premium prices for products and services (Menon and Menon, 1997).

Creating new markets could entail developing new investment products for customers interested in sustainable investing and/or attracting new classes of customers to existing and new product offerings (Riedl and Smeets, 2017). There are also incentives not directly related to financial risks such as those associated with reducing reputational risks and risks associate with potential future regulatory framework related to sustainability (Haufler, 2013). In addition, the academic literature identifies additional incentives associated with broader forces such as the legitimacy of the organization and institutional-oriented drivers connected to operating at a societal level (De Villiers and Van Staden 2006; Brammer, Jackson, and Matten 2012).

\section{Features of sustainability-linked bonds}

A variation to the above-mentioned bonds is the so-called sustainability-linked bonds (SLBs) or ESG bonds. The proceeds of SLBs are intended for general purposes and due to the variability of the coupon based on the accomplishment may be further explored by the Western Balkans countries. During the preparation process objectives are measured through predefined key performance indicators (KPIs) and assessed against predefined sustainability performance targets (SPTs).

The Sustainability-Linked Bond Principles (SLBP) (International Capital Markets Association, 2020) established by ICMA recommend that issuers publicly communicate their rationale for the selection of their KPIs (i.e. relevance, materiality), the motivation for the SPTs (i.e. ambition level, consistency with overall strategic planning and benchmarking approach), the potential change of bond financial and/or structural characteristics and the trigger events leading to such a change, intended post issuance reporting and independent verification. The target setting exercise should be based on a combination of benchmarking approaches that include the issuers' own performance, the performance of its peers and the reference to the science. In this process, the issuer may seek the second party opinion. 
The potential variation of the coupon is the most common example, but it is also possible to consider the variation of other SLB's financial and/or structural characteristics.

What adds to the transparency and the overall credibility of this mechanism is that issuers should seek independent and external verification (for example limited or reasonable assurance) of their performance level against each SPT for each KPI by a qualified external reviewer with relevant expertise, such as an auditor or an environmental consultant, at least once a year.

\section{Debt-for-nature swaps History of Debt-for-Nature Swaps}

(Olshanskaya et al., 2020) provide a historical review of the debt-for-nature swaps. According to the authors, the design and use of the debt swap instrument dates back to the 1990s with the first instruments taking the form of debt-for-equity swaps. Debt restructuring started almost immediately after World War II and accelerated when the Paris Club was founded in 1956 (Cassimon et al., 2014). Comprised of officials from major creditor countries, the club would initiate first large-scale debt relief programs in the form of debt-for-equity swaps, and from 1991 onwards allow debtors to convert their public debt into local payments for social or environmental projects (Cassimon et al., 2011). The first debt-for-equity swap took place in Chile in 1985, where commercial debt was cancelled in exchange for creditors receiving shares in publicly-owned enterprises (Ruiz, 2007).

First debt-for-nature swaps appeared in the 1980 s as a response to the worsening environmental conditions in developing countries. In the 1980 s many countries particularly in Latin America increased their export volume in response to the debt and economic crisis that caused heightened rates of resource exploitation and deforestation. Soon after, the first debt-for-nature swap was agreed upon by Bolivia and Conservation International, in which the latter bought USD 650,000 of Bolivia's commercial debt at a redemption price of USD 100,000 from a Swiss bank. This debt was then swapped against a commitment by the Bolivian government to spend USD 260,000 on biodiversity conservation (Ruiz, 2007).

The volume of debt swaps grew in the 1980s to peak in 1990 and decline through the 1990s. Throughout the 1980s, the secondary market of debt titles grew rapidly (Buckley 1997) and debt swaps were advertised as a standard instrument of debt relief by lending agencies seeking new ways to minimize their financial losses (Cassimon et al., 2011). Total swap volumes, including buybacks and other exchanges, peaked in 1990 at USD 27 billion (Kaiser \& Lambert, 1996), after which they declined in the 1990s. This was partly due to structural adjustments and an improved economic performance of many indebted countries that would increase the value of their debt titles on the secondary market and thereby make them less attractive leverage instruments for environmental groups (Ruiz, 2007; Sheikh, 2011).

Although debt-for-nature swaps were performed at much smaller scales than debt-for-equity swaps, they raised hundreds of million dollars for environmental projects in the 1990s. DFI (2009) estimated that between 1987 and 1997 USD 134 million worth of debt allowed financing of USD 126 million in nature conservation (DFI (Development Finance International), 2009). (Thapa, 1998) estimates the volume to total USD 163 million for the period of $1987-1995$ and according to OECD estimates (Warland \& Michaelowa, 2015), USD 1.1 billion of conservation was financed from debt titles of USD 3.6 billion between $1991-$ 2003.

In the months leading up to the climate summit in Copenhagen, Indonesia named debt swaps as a source of climate finance in informal UNFCCC consultations. Still, debt-for-climate swaps were never declared as an official climate finance instrument under the UNFCCC (Warland \& Michaelowa, 2015). Nevertheless, both the United States and Italy fulfilled parts of their fast-start-finance commitments ( 0.5 and $11 \%$ respectively) for $2010-2012$ via debt swaps, together contributing USD 82.5 million of the USD 30 billion fast-start-finance goal of the Copenhagen Accord (Fenton et al., 2014).

\section{Examples of debt-for-nature swap reported by literature}

Debt relief linked to environmental goals or debt-for-nature swaps is not a new story: after World War II the Paris Club comprised of major creditor countries initiated large-scale debt relief programs in the form of debt-for-equity swaps, and from 1991 onwards allowed debtors to convert their public debt into local payments for social or environmental projects. Since then, debt-for-nature swaps raised hundreds of million dollars for the environment.

A good example among these is a debt swap scheme implemented by Seychelles and a club of public and private debtors which in 2015 enabled the country to cancel EUR 21.6 million in exchange for domestic investments in protection of its unique marine ecosystem against a specific commitment of the Government of Seychelles to increase marine protected area from $1-30 \%$ of its territorial waters (Silver \& Campbell, 2018).

The other good example is a swap between Italy and the Philippines in 2012 that entailed the cancellation of Philippine public debt of EUR 2.9 million in exchange for investments in environmental protection and poverty reduction (Warland \& Michaelowa, 2015). The projects that were in the areas of conservation, reforestation, agriculture, and sustainable resource management placed a particular focus on the participation of local communities. By 2019 , the program is estimated to have 17,000 beneficiaries, including local farmers and fishers from predominantly poor districts.

\section{Features of debt swaps}

As (Olshanskaya et al., 2020) explain, swaps are either arranged directly between one debtor and one or more creditor governments (basic model) or are facilitated by a third party - often an international NGO (tripartite model). In the latter, the NGO purchases the debt of an indebted country at a secondary market price and redeems the debt title with the debtor country in exchange for conservation efforts. The secondary market price ultimately depends on the probability of full debt repayment and is consequently higher if full repayment is expected. In addition, the extent to which the outstanding debt service payments are already written off by the creditor government as well as the overall economic situation and growth projections of the debtor governments play a role. Figure 1 provides an illustration of both models of debt-for-nature swaps. 
After mutual agreement, expenditures of the debtor government are usually made gradually, often into a dedicated fund, and according to the original repayment schedule of initial debt. They can either be channeled directly towards environmental projects or placed in a national trust fund, through which the interest earned on the deposited money can additionally be used to finance environmental projects, e.g., via grants to local NGOs. Such funds allow earmarking and increase accountability by being governed by a committee comprised of representatives from both governments and independent observers, such as national or international NGOs.

If debt titles are bought on the secondary market, the price is determined by the credit rating, debt situation, and overall economic performance of the indebted state. If, alternatively, debt titles are bought back via bilateral agreements, no rules or restrictions on the discount rate by which the initial debt is reduced exist. Having mainly ranged between $0-50 \%$ in the past, discount rates are negotiated between the participating governments on a case by case basis.

Overall, debt swaps are more feasible when creditor governments are willing to sell titles at a price lower than face value, because only then there is some fiscal space created for the debtor government. However, as bilateral debt is predominantly held in US dollars and investments in local environmental projects are generally made in local currency, preferable conditions could arise even at a discount rate of zero when scarce hard currency can be saved.

Most debt swaps have involved bilateral public debt, but debt swaps can also be conducted in the case of multilateral public or commercial debt. Commercial debt, for example, can be bought on the secondary market by a donor country as a form of Official development assistance (ODA) or climate finance. Multilateral creditors, such as the World Bank or the IMF, cannot provide debt relief per se because of their legal status, but donor countries could use their resources to pay off the debt held at such institutions.

Debt-for-climate swaps are commonly referred to as 'win-win' agreements, as they benefit both debtor and creditor countries. Prepared based on (Novikova et al., 2020), Table 1 identifies advantages and shortfalls of debt swaps for the involved parties.

Table 1

Opportunities and challenges of debt swaps for the involved parties

\section{Advantages and positive outcomes for debtor country}

- Through debt relief and conversion, the overall debt burden on the debtor country is

lowered and the strain on the national budget is reduced.

- Since counterpart payments into environmental projects are generally made in local currency, debtor governments save scarce hard currency which they can then use to establish foreign exchange reserves.

- Debt relief can strengthen economic stability, improve the credit rating of a debtor, and attract new investments.

- Environmental projects benefit from freed finance, that would have otherwise gone towards the creditor's budget, often bringing economic and social benefits at a local level.

\section{Advantages and positive outcomes for creditor country}

- From a financial perspective, creditor countries' remaining debt claims increase in value through such swaps, and creditors can recover either full or at least part of their debt and thereby avoid the accumulation of arrears. Debt swaps are particularly beneficial if parts of the debt are already written off and full repayment is unlikely.

- Creditors have to mobilize less additional finance to meet their international climate commitments and, at the same time, can register the instrument as the provision of ODA. Since the nominal value of non-concessional debt can be registered as

ODA, many creditor countries have used this instrument to boost their ODA numbers.

- Further, creditor countries can raise their environmental credentials by mobilizing co-financing through international funding institutions. A dept swap that is carefully designed can guarantee an adequate use of funds and carries a greater responsibility than a single donation.

\section{Shortfalls and challenges}

- If the discount rate is low or even zero, no extra budgetary room is provided, which leaves the overall macroeconomic situation unaffected.

- If the debt swap volume is small, the positive impact on the debtor's economic situation is negligible or might even be outweighed by the costs incurred when negotiating a swap and setting up a trust fund.

- Debtor countries must have sufficient funds to put into trust funds, and there exists a risk of inflation if debtor governments print money to pay the agreed amount in local currency.

- Debt swaps carry the threat of crowding out other forms of finance that are potentially more effective. Debt swaps should be additional to the already delivered ODA and not substitute other channels of new aid.

- Climate-relevant debt swaps have to compete with other sectors (health, education, infrastructure) for a limited amount of eligible debt.

\section{Case study. Debt swap experiences in Montenegro}

The Montenegrin case represents the basic model swap, since it had been arranged directly between debtor and one creditor government. Total debt volume of EUR 11.23 million held by government of Germany, i.e. the KfW bank as the Paris Club creditor was canceled in exchange for project in water supply and sanitation. The Government of Montenegro and the KfW wank were negotiating on the scheme of the swap and agreement was concluded in 2008. The agreement concluded between the KfW bank and Government of Montenegro envisaged cancelation of the debt amount conditioned by fulfilment of several preconditions. The Government of Montenegro as debtor was obliged to contribute amount of EUR 5.6 million to the sewage treatment plant and sewage network in two municipalities under the Program for Water Supply and Sanitation at Adriatic Coast. Contribution was to be made within one-year period from the signing of agreement, paid on special commercial bank account and available for the $\mathrm{KfW}$ inspection. Another precondition was substantial completion of the Program for water supply and sanitation construction works before the end of 2012.

The final consent of the Government of Federal Republic of Germany on the KfW report on completion of program activities was last cancelation precondition. Debtor financial obligation was transferred to special account of Vodacom company organized as Joint Service and Coordination Company for Water and Wastewater Services for the Montenegrin Coast. It was established in 2005, after the Government of Montenegro recognized the need for active work on the improvement of water supply and sewerage infrastructure on the Montenegrin Coast. Last disbursement to the provider of construction works was done in October 2013 by Vodacom which was considered as a closure of the swap. Figure 2 illustrates the architecture of the deal. 


\section{Recommendations for designing debt-for-nature swaps}

(Novikova et al., 2020; Olshanskaya et al., 2020) summarize recommendations from various publications. The authors attest that environmental and fiscal improvements can only be realized when debt swaps are designed carefully, as we saw from the lessons learned. There are three main success factors which ultimately determine the overall effectiveness of the scheme. First is the need to maximize swap's financial value to the debtor country in order to create strong political will and national buy-in. Second, the ambition of the scheme has to be aligned with the national climate goals, and robust monitoring and reporting framework has to be put in place to ensure that its climate impacts are duly monitored and communicated. Lastly, transparent governance arrangements and a well-capacitated operator of the scheme are indispensable for the success.

The first recommendation to a debtor country when designing and negotiating the financial structure of a swap mechanism to maximize the financial values of such schemes:

- Seek to achieve a positive difference between the original face value of the debt and the redemption price so that fiscal space is created. This can be done by either purchasing the debt title on the secondary market or by bilaterally agreeing on applying a discount rate greater than zero with creditor.

- Negotiate the cancellation of the outstanding debt service payments before making counterpart payments in order to provide extra budgetary room.

- Convert the outstanding debt payments into local currency payments so that hard currency can be saved.

- Schedule payments according to the original repayment schedule so that a constant and predictable stream of finance is provided.

- Re-invest the interest rate earned by the funds to provide additional capitalization for the mechanism.

- Only conduct debt swaps if the debt volumes are large enough to justify the lengthy negotiation process and high transaction costs associated with deal structuring and implementation.

Further, debt swaps and corresponding debt relief should be additional to creditor's ODA and not crowd out other ongoing investments in climate mitigation and adaptation. Secondly, climate-related projects funded by debt swaps should be additional to those already funded in debtor countries. While it is beneficial if concrete climate objectives and measures are envisioned and some infrastructure for delivering those is already established, payments originating from swap deals should not be used to legitimize cutting back governmental spending in other areas. And lastly, it would be essential to ensure added finance for the debtor country through debt relief.

The second recommendation is that the design of the climate swap mechanism should be aligned with national climate commitments. In particular, they should be fully anchored in and aligned with national climate change priorities and the objectives as communicated in the National Determined Contributions (NDCs).

In order to ensure the achievement of climate and other environmental and social benefits of climate swap schemes, it is important to start with determining a baseline scenario against which progress and final outcomes are measured. This entails developing indicators and specific defining targets that should be set for various steps throughout the implementation phase. Monitoring plans and methodologies shall also be developed to enable regular progress tracking, reporting and communication to all involved stakeholders and public at large to enhance transparency. Involvement of independent actors, such as NGOs, has proven to facilitate trust between debtor and creditor government and has been crucial for encouraging civil society participation. While some international NGOs have gathered extensive experience in facilitating debt-for-nature swaps, the contribution of local or regional NGOs is similarly important to provide crucial insights about local conditions.

The third recommendation is that effective implementation and governance structures are essential for the success of the swap mechanism. This, first of all, calls for an establishment of a scheme operator, or a selection of one from existing organizations. This should be a financial institution with solid fund management expertise and technical capacities to implement climate projects. Such combination of financial and climate expertise rarely exists in developing countries and often has to be built from scratch with additional technical assistance from international organizations. In addition, to ensure oversight and provide strategic guidance, a good practice is to establish a supervisory committee that is comprised of representatives from both the debtor government and the creditors as well as international and national NGOs.

The debtor government's leading role and close involvement in designing and implementing a swap deal is crucial to ensure national ownership and longevity of the programme. At the negotiation stage, highest level political support of the climate swap proposal has particularly proven to be decisive for the deal to happen. Climate-related projects should be anchored in national climate policies, and debt swaps should be embedded in a broader debt reduction strategy.

\section{Results: Adopting New Instruments In The Western Balkans Public debt and feasibility of instruments in Western Balkans 6}

For the purpose of reviewing the public debt conditions in the WB6 countries, the trends of debt in the ten-year period 2010-2020 was assessed. Given that the entire decade has been post-crisis, following the global financial crisis in 2008, it is to be expected that each of the countries will record an exponential trend of public debt growth. The new Covid-19crisis period begun in 2020, which is primarily characterized by a decline in GDP and an increase in public debt is expected due to the need to finance the health sector as well as economic support programs.

What is noticeable in methodological terms is that there is no consistency in public debt reporting methodology of the Western Balkan countries. Each country has its own approach to reporting. However, over a ten-year period, improvements in the quality and coverage of reports, as well as levels of transparency, are 
very evident. Table 2 provides an overview of the data on public debt, its ratio to gross domestic product (GDP), as well as the structure of the public debt portfolio of the WB6 countries.

Table 2 illustrates that the condition of WB6's public debt at the end of 2020ranges widely, from $24 \%$ in Kosovo to $102 \%$ in Montenegro. The trend of the debt movement was continuously progressive, except in Serbia and Bosnia, which in the second part of the period, after 2015, managed to reduce the share of public debt in GDP. Other countries have managed to double, and some have tripled, their public debt in the past decade.

Five countries, except North Macedonia have fiscal rules in place. All of them have a rule limiting debt, but there are differences in a size and nature of the limit. Size of the limit differs form 40\% in Kosovo, 45\% in Albania and Serbia and 60\% in Montenegro and Bosnia and Herzegovina (Kikoni et al., 2019). It is clear that all countries, except Bosnia and Herzegovina and Kosovo, have been violating this fiscal rule for some time. The COVID crisis is likely to further slow these countries' ability to comply with the public debt limit. The public debt of the WB6 countries is predominantly external, except in Kosovo, where, starting in 2015 , the situation is changing in favor of domestic debt. Also, public debt is dominant and euroized in countries that have their own currency.

As for the public debt portfolio, each of the countries has certain specificities, depending on the economic and political heritage. Those who had liabilities based on old foreign currency savings, restitution and unpaid pensions have securitized them and are present in the portfolio of their domestic debt. Each of the countries in its portfolio has loans from multilateral and bilateral creditors, government securities, euro-bonds and private sector creditors loans.

At the beginning of the decade, multilateral and bilateral creditors loans were most dominant in the public debt portfolio, and over time their share decreased with the exception of Bosnia and Herzegovina, where these loans continuously participate with about $70 \%$ in the total portfolio. The decrease in the share of these loans in most countries was in favor of the increase in the share of government securities, this time with the exception of Montenegro, which has changed the structure of its portfolio in such a way that euro-bonds and private sector loans have become the most important means of financing public debt.

Government securities involve the issuance of bonds and treasury bills. The fact that North Macedonia, Serbia, Kosovo and Albania have $30-60 \%$ of these securities in their portfolio speaks not only of domestic confidence, but also of the capacities of domestic banks and institutional investors.

The fact that all countries except Kosovo and Bosnia and Herzegovina, and some even before 2010 had successful euro-bond issues, also indicates the presence of confidence of international investors.

When it comes to the debt maturity, countries do not usually publish a single average maturity figure. Data which are mainly given refer to the maturity structure, which show that long-termsecurities are predominantly present in the portfolio. Specifically, Montenegro published data that the average maturity at the end of 2020 was 6.9 years, while the same data for Bosnia and Herzegovina for 2019 was 7.7 years. Also, the ratio of debt to fixed and variable rates in most countries is in favor of fixed or is balanced.

All of the above leads to the conclusion that Western Balkans 6 will have a specific challenge to manage their public debt in this so-called traditional way. It will be particularly interesting how and to what extent the governments of these countries will know how to recognize and be able to introduce new borrowing instruments.

One of the modalities recently proposed by the IMF researcher (Willems, 2021) based on the Klemperer'sProduct-Mix Auction approach. It is proposed to hold auctions overcome issues related to the classic sovereign debt restructuring negotiations. The application of an auction model offers a platform that enables participants to engage based on their preferences rather than one-size-fits-all approach, which causes enormous difficulties. Such preferences may relate to bonds different in maturity or denominated in different currencies.

Table 2. Public debt portfolio of the Western Balkan 6 countries

\begin{tabular}{|c|c|c|c|c|c|c|c|c|c|c|c|c|c|c|c|c|c|c|}
\hline & \multicolumn{3}{|c|}{ Montenegro } & \multicolumn{3}{|c|}{ North Macedonia } & \multicolumn{3}{|l|}{ Serbia } & \multicolumn{3}{|l|}{$B \& H$} & \multicolumn{3}{|c|}{ Kosovo } & \multicolumn{3}{|c|}{ Albania } \\
\hline & 2010 & 2015 & 2020 & 2010 & 2015 & 2020 & 2010 & 2015 & 2020 & 2010 & 2015 & 2020 & 2010 & 2015 & 2020 & 2010 & 2015 & 2020 \\
\hline Public debt \% GDP & 42 & 61.6 & 102.4 & 24.6 & 38 & 60.2 & 42.9 & 76 & 56.8 & 33.8 & 40 & 35 & 6.2 & 13.0 & 24.6 & 57.7 & 72.8 & 77.9 \\
\hline \multicolumn{19}{|l|}{ Public debt portfolio (\% of total public debt) } \\
\hline Multilateral and bilateral creditor loans & 46.4 & 27.7 & 13.7 & 49.2 & 25 & n.a. & 46.6 & 35 & 37.8 & 66.6 & 70.4 & 68.5 & n.a. & 49.25 & 33 & 18.9 & 25.7 & 25.6 \\
\hline Eurobond & 15.7 & 39.6 & 44.9 & 19 & 22.3 & n.a & 0 & 19 & 19 & 0 & 0 & 5.4 & n.a. & 0 & 0 & 3.36 & 4.31 & 9.05 \\
\hline Government securities & 3.9 & 4.37 & 4.2 & 31.3 & 38.9 & n.a. & 47.5 & 30.5 & 39.5 & 11 & 10.4 & 15.8 & n.a. & 50.5 & 64.7 & 32.41 & 36.32 & 40.12 \\
\hline
\end{tabular}

Source: Statistical Offices and Ministry of Finance websites of WB6 (Montenegro: www.mif.gov.me (Ministry of Finance), www.monstat.org (Statistical Office) Serbia: www.javnidug.gov.rs (Public Debt Administration), North Macedonia: www.finance.gov.mk (Ministry of Finance), www.stat.gov.mk (Statistical Office), Albania: www.financia.gov.al (Ministry of 
Finance), www.instat.goval (Statistical Office), Bosnia and Herzegovina: www.mft.gov.ba (Ministry of Finance), www.bhas.gov.me (Statistical Office), Kosovo: www.mf.rks-gov.me (Ministry of Finance) www.ask.rks-gov.net (Statistical Office))

The swap scheme's new lease of life?

Given the analysis of the fiscal positions of the countries of the WB6 it is clear that further macro fiscal deterioration may be expected as countries face the impact of the Covid-19 crises. In the context of the of the EU accession process and the recently revealed European Green Deal, newly shaped market mechanisms for the UN2030 Agenda financing in the form of the green, social or sustainability bonds it is worth considering whether a further innovation is possible. This innovation may arise from already existing debt-for-nature swap which can trace its way back to the post WWII debt restructuring and later debtfor-equity instruments as explained in literature review. As explained one of the countries that has used this opportunity was Montenegro in 2009.

On the other hand it is evident that the EU is a willing partner and provides different mechanism of support. We will mention here the most important one, socalled Instrument of Pre-accession Assistance which begins its third 2021-2027 iteration. IPA serves to provide financial assistance to the candidate countries in order to meet political and economic criteria for the membership and is based on the strategic documents which point out necessary reforms in the fields of the rule of law, fundamental rights and governance; socio-economic development; Union policies and acquis; people-to-people contacts and reconciliation, good neighbor relations and regional cooperation. Expanding the previous IPA II mechanism to the areas of migration, security, protection of the environment and climate change should be the new feature. In fact, the debate in the Parliament during the first reading produced amendments which assuming Paris Agreement obligations aim at stronger connection between UN 2030 Agenda and IPA claiming the need to allocate 16\% of the Program to the climate impact need in the beneficiaries. It also calls for the special attention to the cross-border polluting issues. Equally Parliament call for the European Fund for Sustainable Development plus to complement the efforts under the pre-accession programme (European Parliament, 2019; The European Parliament, 2019).As for the IPA III assistance purpose approximately EUR 14.5 billion has been proposed it would mean tagging more that EUR 2 billion for the climate related investments. Such allocation if finally approved in such form, could be an excellent leverage to generate lot more funding from the capital markets.

The debt analysis of the WB6 countries despite somewhat different situations clearly point out that there are many macro-fiscal challenges ahead and an innovative approach is needed. At the same time despite having relatively reduced fiscal space for additional borrowing while many structural requirements lie ahead it is obvious that individual countries GDP in purchase power is still significantly lagging behind the EU average, as Table 3 illustrates.

\section{Table 3. WB6 GDP per capita in PPS}

\begin{tabular}{|l|l|}
\hline & \% of EU average in 2019 \\
\hline EU 27 average & 100 \\
\hline Montenegro & 50 \\
\hline Serbia & 41 \\
\hline North Macedonia & 38 \\
\hline Bosnia and Herzegovina & 32 \\
\hline Albania & 31 \\
\hline
\end{tabular}

Source: Eurostat https://ec.europa.eu/eurostat/web/products-datasets/

With average score of $38^{[1]}$ in 2019 year before the pandemic begun it is obvious how far countries need to go, and why any innovative mechanism is more than needed. It is only that sustainable development and a continuous positive trajectory can keep this part of the world secure and migration at bay.

Bringing together IPA and private markets, while combining the swap model and the new forms of issuing bonds which is more transparent and requires vigilante reporting and later verification, EU may further support countries of the Western Balkans by repaying part of the principal debt upon the independent verification of how proceeds are used and whether targets have been met. This can particularly be directly linked with the complementary Green Agenda for Western Balkans (European Commission, 2020) establishing number of initiatives in the different areas such as climate change, clean energy transmission, smart and sustainable mobility, circular economy, depopulation, sustainable food systems and rural areas and the protection of the biodiversity. In parallel to that Western Balkans countries should continue their accession process which means conducting series of different policies in order to join EU one day. Table 4 presents the KPls that are used to help measure the EU's contribution to the achievements of the candidate countries:

It is noticeable that there is no mention of the Human Development Index produced by the UNDP, which would also be of use when tracking the progress in the social sphere related to the education and health in particular.

\section{Could green, social and sustainability bonds be a good fit?}

Going back to the green, social and sustainability or ESG bonds in some form, they have key performance indicators and sustainable targets. Given that the European Commission uses different key performance indicators to monitor the progress the countries make those indicators could play important role. At the same time, the Green Agenda for Western Balkans sets off number of initiatives that could be transferred into the targets, both indicators and these targets can serve as an excellent basis for transparency and reporting required by the markets.

The availability of IPA III funds completes the picture as those resources can be used for the adjusted swap mechanism and used to pay for the fraction of issued green, social, sustainability bonds. Paying for that in the maturity year sets free additional resources in the troubled state budgets. Another option could be to issue higher amount of bonds while the markets realize that providing the implementation of the policies and meeting targets means that EU would use 
some of the funds to repay part of the bonds once they mature. Such mechanisms would bring another relief in the lower interest that would be paid each year, which provides additional financial means to implement the EU acquis. Altogether, countries could benefit from spurring economic growth based on sustainable and smart development while keeping public debt checked.

What exact targets and what exact portion of the bonds would be repaid by the IPA III allocation would depend on the type of a bond given different levels of support EU provides to the different areas of investments.

Some of the initiatives may easily be turned into clear targets some would need further work to figure out the most proper indicators. For example, as far the initiative related to the Biodiversity Action plan is concerned, first target might be the adoption of a proper action plan followed by some key action points to be carried out.

The work of the SDG indicators as well as the efforts and the contribution of the UN Global Compact may help tremendously to that cause. This may also be the field of the further research.

\section{Summary of recommendations}

Figure 5 presents our summary of recommendations for the establishment of new financial instruments in the Western Balkans.

Obviously there are plenty of different possibilities to use some of the innovative models. The one which has been summarized below, takes off from the current macroeconomic situation in the Western Balkans explained above, which suggests many a structural issue to be tackled by the national governments.

All the WB6 countries stream to become member states of the EU. However, that road demands introduction of the very specific legislation which normally brings about the need to accommodate and adjust institutions requiring additional costs and more efficient and effective public administration in the end. Additionally infrastructure and overall development needs remain very high and macro-fiscal room has shrunk given the levels of the public debt in particular.

Therefore the innovative approach presented below offers a new modality of ESG bonds which are based on the EU process combined with the Green Agenda initiatives for the Western Balkans. This new bond mechanism would use some of the lessons and practicalities learned from the nature for debt swaps where green investments could lead to some debt relief. Countries should be encouraged to define clear targets based on the sustainable development policies and then go to the market with the transparent support of the EU through the IPA funds. The logic of the IPA funds is to prepare countries for the membership and are used to help meet various benchmark. Even the modality by which countries benefit from the direct budget support is conditioned by some prior action.

This new approach would bring about the synergy between private and public funds, would introduce very transparent targets and indicators verifiable by the independent auditors and would use the IPA funds as a powerful leverage that can help save some interest or principal repayment cost and thus help a country lower their public debt and reinforce their international financial credibility or use the extra money for additional investments into the quality of the public administration or social infrastructure. Instead of chopping IPA between different sectors it would be more transparent and effective to use the contribution as an additional verification of the proper policies in place (it may combine rule of law with public administration reforms or sustainable development). Such an approach would increase accountability of the policymakers as well.

It would be crucial to develop more measurable targets as far as the Green Agenda for the Western Balkans initiatives are concerned. Other indicators which are reported by the international organizations (World Bank's Doing Business for example are more straightforward). Evidently in some cases it takes new legislation to be produced, in other to implement. Any initiative which is measurable through additional regional mechanisms of cooperation is a value added as it contributes to the stability and prosperity of the whole area.

\section{Conclusion}

The promise of the EU made in 2003 that all the Western Balkans countries are welcome to join EU once the criteria are met, has set the most of the policy goals for these countries. However, since then only Croatia joined on the July 1, 2013 while the rest seem to be stuck for the time being. Whereas Montenegro has advanced the most in the accession process (all the negotiating chapters are open) and Serbia following, the process still lags behind in other countries. North Macedonia and Albania are still waiting for the real accession talks to begin, whereas Bosnia and Herzegovina and Kosovo seem to be nowhere near to the beginning.

In the meantime, the UN 2030 Agenda adopted in 2015 setting the SDGs as well as the ongoing challenges related to the Covid 19 have put additional ingredients on the table. The green transition has become equally important policy for the respective countries and along with that additional social and economic challenges emerge. Economically speaking the situation is complex and all the Western Balkans 6 countries are faced with significant development financing needs. Their average GDP in terms of the purchase power compared to EU average is way below $50 \%$. While the average public debt stands at around $50 \%$ the figure which may seem moderate hides the growing trend over the past decade and big discrepancies among the countries like Montenegro and Albania on the one hand and Kosovo for example on the other.

Therefore, the complex agenda involving EU accession, infrastructure and SDG needs requires innovation in the SDG financing.

This paper analyses some of the new mechanisms such as green, social and sustainability bonds on the one hand and nature for debt swaps on the other. It is obvious that some of the main benefits of the new form of the ESG bonds is a higher level of transparency and inevitably higher level of accountability that come along. In order to achieve benefits such as lower interest rate of the longer maturity it is important to incorporate independent verification whether the various KPIs and green/social/sustainability targets are met. 
On the other hand nature for debt swaps are not entirely new and have been in place for some decades. Out of the six WB countries it seems that only Montenegro used it successfully once at the end of the first decade of the 21 st century. However, many other countries have used them and number of useful lessons and practical pieces of advice can be generated.

Put together ESG bonds along with nature for debt swaps in the light of the EU accession of the Western Balkans countries can offer the basis for another layer of innovative financing and that is the key recommendation of this paper. Countries should feel encouraged to enter the private markets clearly stating their green and de-carbonization development plans and define policy goals that stem from the European green deal and the Green agenda for the Western Balkans which has to be combined to the new cluster like methodology European commission applies to conduct accession talks with the candidate countries. That assumes developing policy targets and indicators independently verifiable as the whole agenda grows more and more complex which each stage.

Such innovative approach to the markets could also encourage EU to adjust the ways pre-accession support is used (IPA III as it is called in this cycle) as those funds could be extremely useful leverage to access private markets and accelerate investment cycle by providing synergy between the huge opportunities private markets bring, with the crucial support of the public funds coming from the EU.

The previous Paris Club debt-for-nature modalities can bring another element into the picture providing the logic of a swap, which together with possibly the new approach to the debt sustainability offered by IMF researchers may result in the win-win situation for all the players. Hopefully, it may unlock missing fiscal space, which in the mid to the long term could bring about many benefits in the higher level of GDP and higher level of human development indexes.

\section{Abbreviations}

IPA - Instrument for Pre-Accession Assistance of the EU to the candidate countries

ESG - Environmental, Social and Governance

KfW - Kreditanstalt fur Wiederaufbau

SDG - Sustainable Development Goals based on UN 2030 Agenda

UNFCCC - United Nations Framework Convention on Climate Change

UNDP - United Nations Development Program

WB6 - Western Balkan 6 (Albania, Bosnia and Herzegovina, Kosovo, Montenegro, North Macedonia, Serbia)

\section{Declarations}

\section{Ethics approval and consent to participate}

Not applicable

\section{Consent for publication}

Not applicable

\section{Availability of data and materials}

The datasets used and/or analyzed during the current study are available at the following links: - Montenegro:www.mif.gov.me (Ministry of Finance), www.monstat.org (Statistical Office) - Serbia: www.javnidug.gov.rs (Public Debt Administration),

-North Macedonia: www.finance.gov.mk (Ministry of Finance), www.stat.gov.mk (Statistical Office),

- Albania: www.financia.gov.al (Ministry of Finance), www.instat.goval (Statistical Office), - Bosnia and Herzegovina: www.mft.gov.ba (Ministry of Finance), www.bhas.gov.me (Statistical Office),

-Kosovo: www.mf.rks-gov.me (Ministry of Finance) www.ask.rks-gov.net (Statistical Office)

- https://ec.europa.eu/eurostat/web/products-datasets/

\section{Competing interests}

Authors declare that they have no competing interests

\section{Funding}

Not applicable

\section{Authors' contribution}


IL developed the key recommendation of the proposed ESG bond supported by the EU IPA funds. BB analyzed Western Balkans countries macroeconomic and macro-financial situation generating basis for the development of the recommendation. AN provided literary overview and the theoretical background of the nature for debt swaps and RV analyzed the innovative bond instruments providing examples and the basis for the recommendation development.

\section{References}

1. Brammer, S. , Jackson, G., Matten, D. (2012). Corporate Social Responsibility and Institutional Theory: New Perspectives on Private Governance. SocioEconomic Review 10 (1): 3-28.

2. Branco, M., C., Rodrigues, L. (2006). Corporate Social Responsibility and Resource-Based Perspectives. Journal of Business Ethics 69 (2): $111-132$.

3. Climate Bond Initiative. (2020). 2019 Green Bond Market Summary. https://www.climatebonds.net/files/reports/2019_annual_highlights-final.pdf

4. Cassimon, D., Essers, D., \& Fauzi, A. (2014). Indonesia's Debt-for-Development Swaps: Past, Present, and Future. Bulletin of Indonesian Economic Studies, 50(1), 75-100. https://doi.org/10.1080/00074918.2014.896238

5. Cassimon, D., Prowse, M., \& Essers, D. (2011). The pitfalls and potential of debt-for-nature swaps: A US-Indonesian case study. Global Environmental Change, 21(1), 93-102. https://doi.org/10.1016/j.gloenvcha.2010.10.001

6. Climate Bonds Initiative. (n.d.). Explaining green bonds. https://www.climatebonds.net/market/explaining-green-bonds

7. Climate Bonds Initiative. (2020). 2019-Global Green Bond State of the Market. https://www.climatebonds.net/files/reports/cbi_sotm_2019_vol1_04d.pdf

8. Committee, E. E. and S. (2018). Proposal for a Regulation of the European Parliament and of the Council establishing the Instrument for Pre-accession Assistance (IPA III) [COM(2018) 465 final - 2018/0247 (COD)]. https://webapi2016.eesc.europa.eu/v1/documents/EESC-2018-04092-00-00-AC-TRAEN.docx/content

9. De Villiers, Ch.m, Van Staden, Ch.( 2006). Can Less Environmental Disclosure Have a Legitimising Effect? Evidence from Africa. Accounting, Organizations and Society 31 (8): 763-781.

10. DFI (Development Finance International). (2009). Debt relief to combat climate change.

11. Environmental Finance Bond Dabatase. (n.d.). Various statistics. https://www.bonddata.org/

12. EU Technical expert group on sustainable finance. (2019). Teg Report Proposal for an Eu Green Bond Standard (Issue June).

13. Haufler, V. (2013). A Public Role for the Private Sector: Industry Self-Regulation in a Global Economy. Washington, DC: Carnegie Endowment for International Peace.

14. Hockerts, K. (2015). A Cognitive Perspective on the Business Case for Corporate Sustainability." Business Strategy and the Environment 24 (2): $102-122$.

15. European Commission. (2019). Communication from the Commission to the European Parliament, the Council, the European Economic and Social Committee and the Committee of the Regions. The European Green Deal. Brussels, 11.12.2019 COM(2019) 640 final.

https://ec.europa.eu/info/sites/default/files/european-green-deal-communication_en.pdf

16. European Commission. (2020). Guidelines for the Implementation of the Green Agenda for the Western Balkans Accompanying the Communication from the Commission to the European Parliament, the Council, the European Economic and Social Committee and the Committee of the Regions An Econom. https://ec.europa.eu/neighbourhood-enlargement/sites/near/files/green_agenda_for_the_western_balkans_en.pdf

17. Taxonomy: Final report of the Technical Expert What is the EU Taxonomy?, European Commission - European Commission 67 (2020). https://ec.europa.eu/info/files/200309-sustainable-finance-teg-final-report-taxonomy_en

18. European Parliament. (2019). European Fund for Sustainable Development. http://www.europarl.europa.eu/RegData/etudes/ATAG/2017/607289/EPRS_ATA(2017)607289_EN.pdf

19. EUROSTAT. (n.d.). Eurostat statistics. https://ec.europa.eu/eurostat/web/products-datasets/

20. Fenton, A., Wright, H., Afionis, S., Paavola, J., \& Huq, S. (2014). Debt relief and financing climate change action. Nature Climate Change, 4(8), 650-653. https://doi.org/10.1038/nclimate2303

21. ICMA. (2019). Green Project Mapping. In International Capital Market Association (Issue June). https://www.icmagroup.org/green-social-andsustainability-bonds/green-bond-principles-gbp/

22. International Capital Market Association (ICMA). (2020). Social Bond Principles. In The Social Bond Principles (Issue June). https://www.icmagroup.org/green-social-and-sustainability-bonds/social-bond-principles-

sbp/\%0Ahttps://www.icmagroup.org/assets/documents/Regulatory/Green-Bonds/June-2020/Social-Bond-PrinciplesJune-2020-090620.pdf

23. International Capital Markets Association. (2020). Sustainability-Linked Bond Principles. In International Capital Markets Association (Issue June). https://www.icmagroup.org/assets/documents/Regulatory/Green-Bonds/June-2020/Sustainability-Linked-Bond-PrinciplesJune-2020-100620.pdf

24. Kaiser, J., \& Lambert, A. (1996). Debt swaps for sustainable development.

25. Kikoni, E., Madzarevic-Sujster, S., Irwin, T., \& Jooste, C. (2019). Fiscal Rules for the Western Balkans. In Fiscal Rules for the Western Balkans (Issue August). https://doi.org/10.1596/1813-9450-8990

26. Kerencheva, E. (2021). Pfizer Issues \$1 Billion Sustainability Bond, Proceeds to Fund COVID-19 Vaccine R\&D. ESG Today.

27. Maltais, A., Nykvist, B. (2020) Understanding the role of green bonds in advancing sustainability, Journal of Sustainable Finance \& Investment.

28. Menon, A., Menon, A. (1997). Enviropreneurial Marketing Strategy: The Emergence of Corporate Environmentalism as Market Strategy." Journal of Marketing 61 (1): 51-67.

29. Novikova, A., Olshanskaya, M., Hoppe, J., \& Grigoryan, E. (2020). Debt-for-climate swaps. IKEMClimateFinanceWeek: IKEM Brief. https://www.ikem.de/wpcontent/uploads/2021/05/Brief.2_Dept-for-nature-swaps.pdf

Page $12 / 16$ 
30. Olshanskaya, M., Novikova, A., Hoppe, J., \& Grigoryan, E. (2020). Evaluating the fiscal and environmental efficacy of debt-for-climate swaps: Using global case studies to derive recommendations for countries of Central Asia and Caucasus. Working Paper (Issue June). https://www.ikem.de/wpcontent/uploads/2021/05/Olshanskaya-Novikova-Hoppe-Grigoryan-_-Debt-for-climate-swaps-Caucasus-Central-Asia-_IKEM.pdf

31. Pandit, R., Prakriti, C., Centre, R., Köhler, M., Dransfeld, B., \& Nettersheim, C. (2017). Status quo of international Adaptation Finance (Issue November 2017). https://www.thegreenwerk.net/publications/Status_quo_of_international_Adaptation_Finance.html

32. Peeters, S., Schmitt, M., \& Volk, A. (2020). Social Bonds Can Help Mitigate the Economic and Social Effects of the COVID-19 Crisis. In EMCompass Emerging Markets. https://www.ifc.org/wps/wcm/connect/ec548185-5e62-4f34-86db-b4d92872cd8e/EMCompass-Note-89-Social-Bonds-COVID-19.pdf? $M O D=A J P E R E S \& C V I D=n g S Z y 60$

33. Riedl, A., Smeets, P., (2017). Why Do Investors Hold Socially Responsible Mutual Funds?" The Journal of Finance 72 (6): $2505-2550$.

34. Rich, B. (2013). Mortgaging the Earth: The World Bank, environmental impoverishment, and the crisis of development. Routledge.

35. Ruiz, M. (2007). Debt swaps for development: Creative solution or smoke screen? (Issue October).

36. SCF UNFCCC. (2018). Report on the 2018 Forum of the Standing Committee on Finance - Climate finance architecture: enhancing collaboration, seizing opportunities Executive Summary (Issue October). https://unfccc.int/sites/default/files/resource/2018 SCF Forum Report_Final.pdf

37. Sheikh, P. A. (2011). Debt-for-nature initiatives and the tropical forest conservation act: Status and implementation. Federal Conservation Efforts, Programs and Funds, 116-133.

38. Silver, J. J., \& Campbell, L. M. (2018). Conservation, development and the blue frontier: the Republic of Seychelles' Debt Restructuring for Marine Conservation and Climate Adaptation Program. International Social Science Journal, 68(229-230), 241-256. https://doi.org/10.1111/issj.12156

39. Thapa, B. (1998). Debt-for-Nature Swaps: An Overview. International Journal of Sustainable Development \& World Ecology., 5(4), $249-262$.

40. The Economist. (2021). Climate finance: It is not easy being green. The Economist.

41. The European Parliament. (2019). European Parliament legislative resolution of 27 March 2019 on the proposal for a regulation of the European Parliament and of the Council establishing the Instrument for Pre-accession Assistance (IPA III) (COM(2018)0465 - C8-0274/2018 - 2018/0247(COD)) https://www.europarl.europa.eu/doceo/document/TA-8-2019-0299_EN.pdf

42. UNSDG. (2018). Local insights, global ambition. https://unsdg.un.org/resources/unlocking-sdg-financing-findings-early-

43. Warland, L., \& Michaelowa, A. (2015). Can debt for climate swaps be a promising climate finance instrument? Lessons from the past and recommendations for the future. www.perspectives.cc

44. Willems, T. (2021). A proposal for an auction-based sovereign debt restructuring mechanism. https://www.google.com/url?

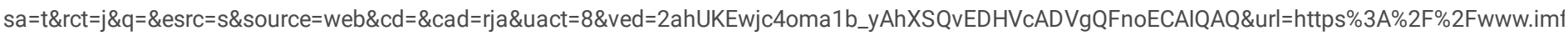
Annual\%2520Meetings\%2FSM21\%2Fopenevents\%2FAn\%2520Auction-

Based\%2520Sovereign\%2520Debt\%2520Restructuring\%2520Mechanism.pdf\&usg=AOvVaw2TurofxYmNsJyuuPYVm6EC

45. World Bank. (2017). The Green Bond Market: 10 years later and looking ahead.

https://pubdocs.worldbank.org/en/554231525378003380/publicationpensionfundservicegreenbonds201712-rev.pdf

46. https://www.sdfinance.undp.org/content/sdfinance/en/home/solutions/green-bonds.html

47. https://www.weforum.org/agenda/2021/03/rescheduling-debt-climate-sustainable-recovery/

48. https://www.esgtoday.com/pfizer-issues-1-billion-sustainability-bond-proceeds-to-fund-covid-19-vaccine-rd/

\section{Table}

Table 4 is not available with this version.

\section{Figures}


BASIC MODEL

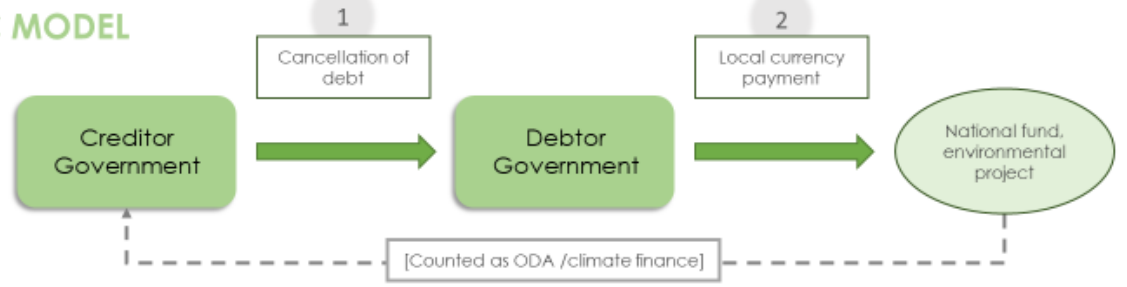

TRIPARTITE MODEL

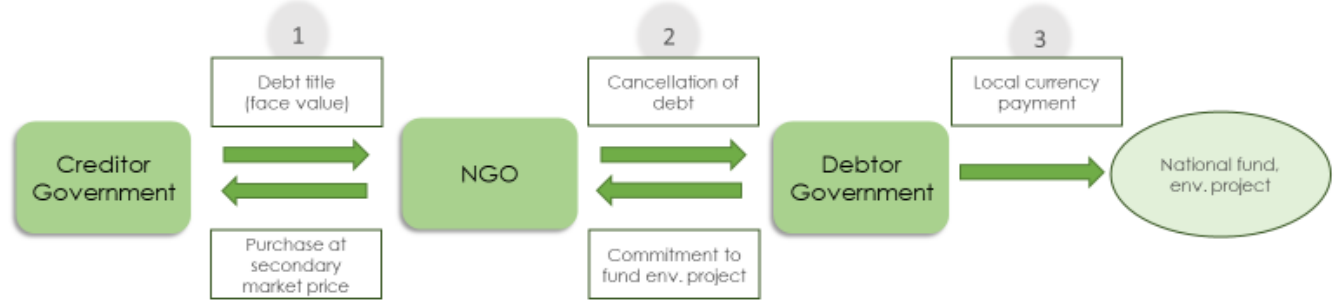

\section{Figure 1}

The architecture of debt-for-nature swap instruments (Olshanskaya et al., 2020)

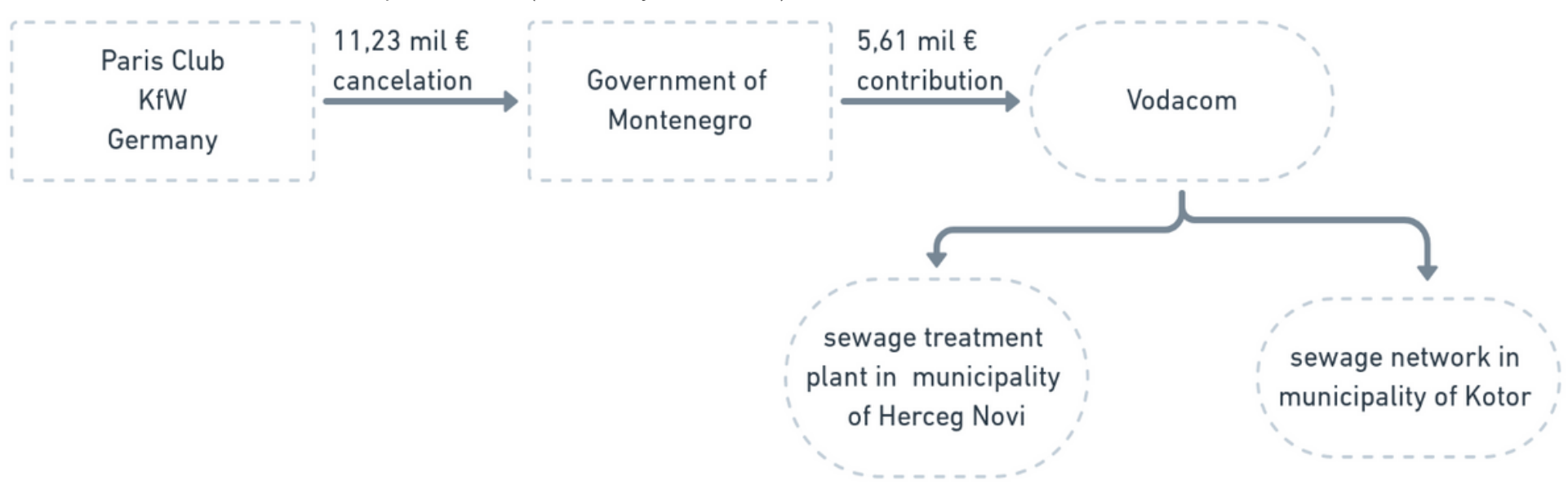

Figure 2

Overview of the debt to nature swap between the Paris Club and Montenegro 


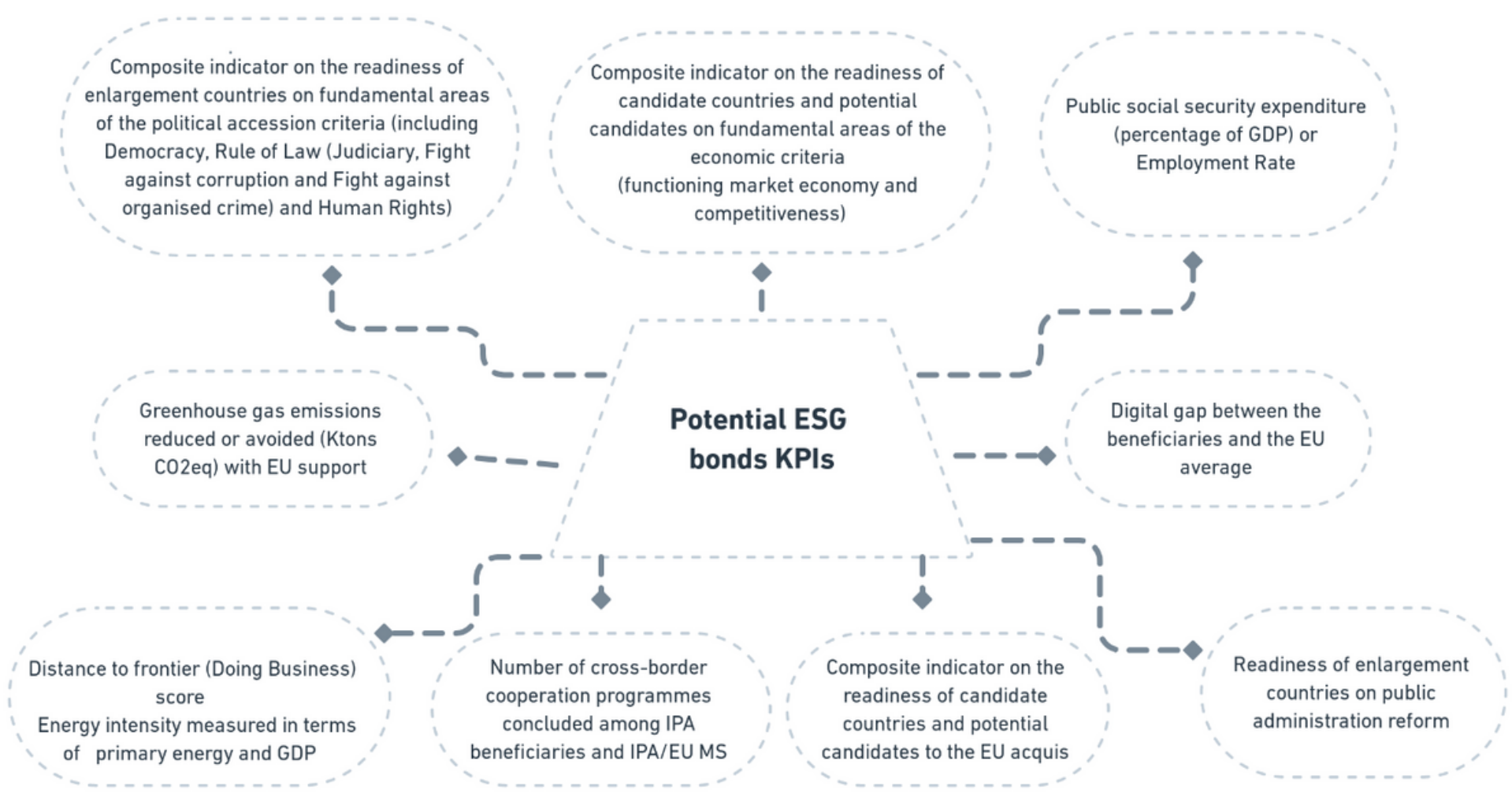

Figure 3

List of Key Performance Indicators (Committee, 2018)

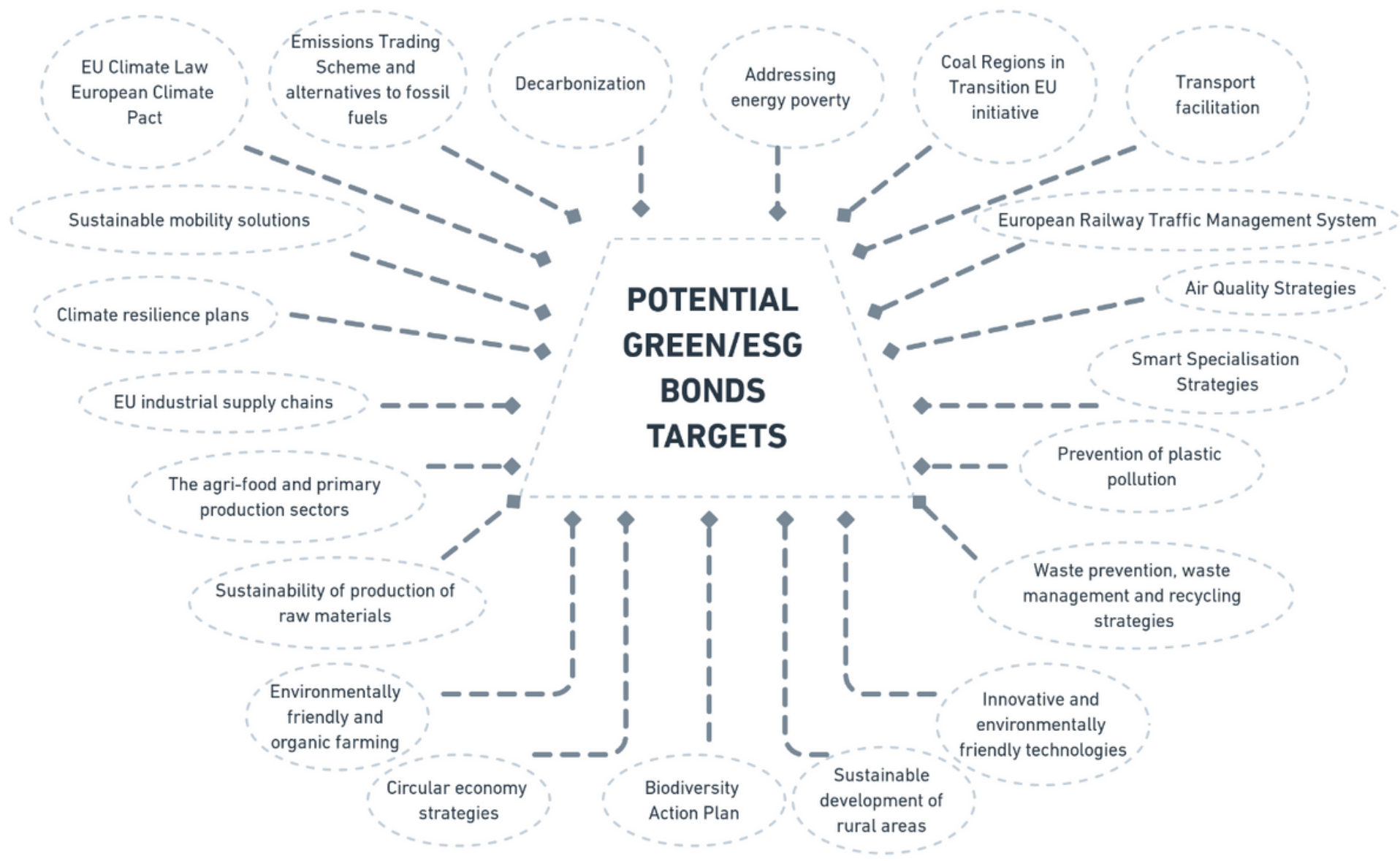

Figure 4

Green Agenda for Western Balkans Initiatives 
Innovative approach based on nature for debt concept, IPA funds that support meet accesion benchmarks ad structure of ESG/green bonds

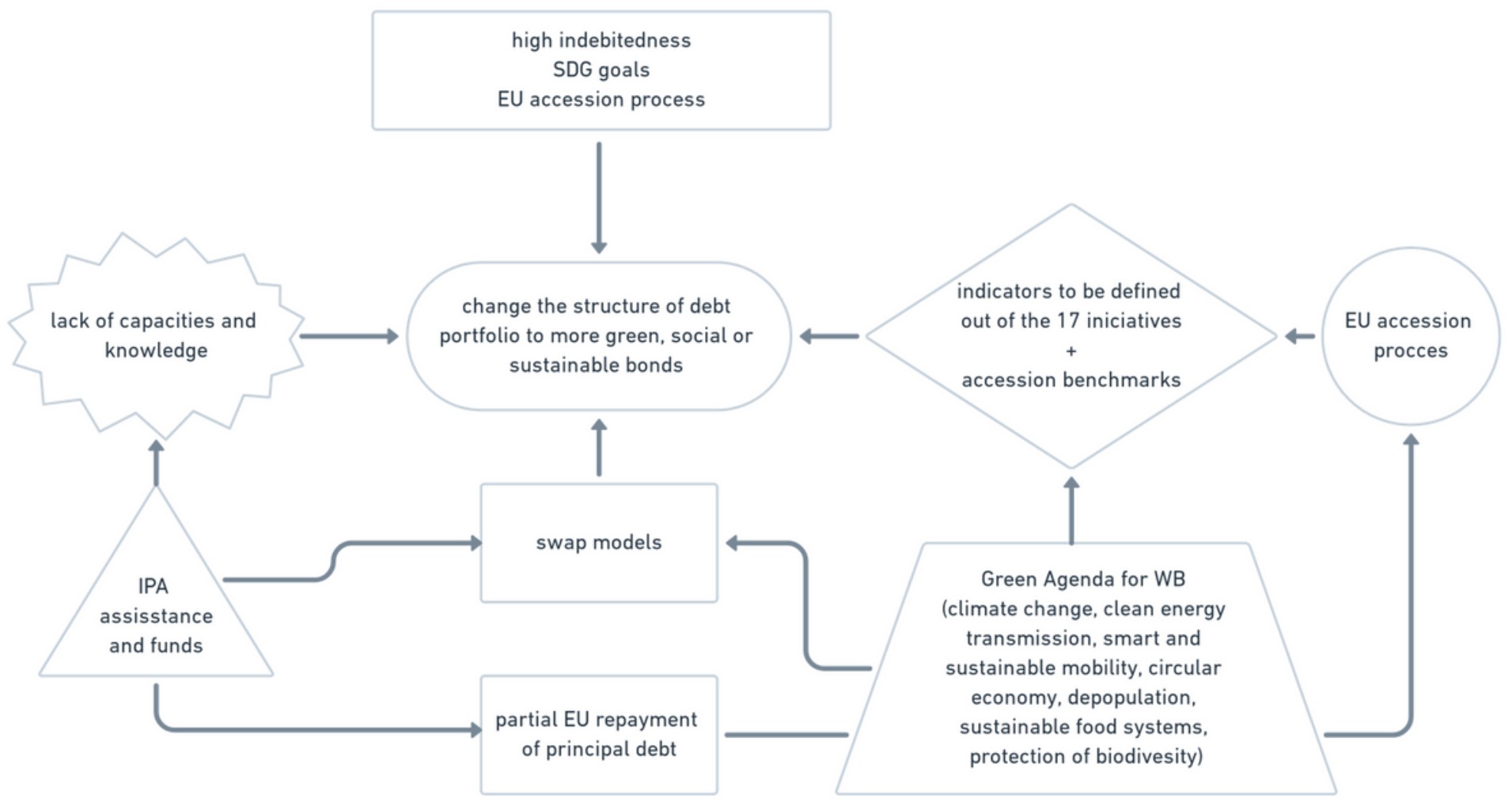

Figure 5

Summary of recommendations on the introduction of new financial instruments in the Western Balkans 